\title{
Research on the Influence of Real Estate Investment and Economic Growth in China
}

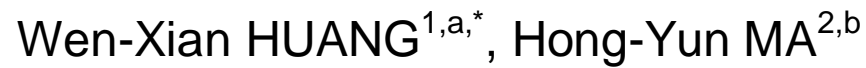 \\ ${ }^{1}$ School of Humanities and Economic Management, China University of Geosciences Beijing \\ ${ }^{2}$ Resource and Environmental Management Lab, China University of Geosciences Beijing \\ awenxian0626@sina.com, bmahy@cugb.edu.com \\ ${ }^{*}$ Corresponding author
}

Keywords: Real estate investment, Economic growth, Asset investment.

\begin{abstract}
Real estate investment has beeninfluncing economic growth and fluctuations more evidently recently. A preliminary analysis on the status of REI, economic growth and fixed investment will be carried out on the relationship between Real Estate Investment and Economic Growth which is based on input-output method and National economic accounting theory. The results show that the influence of Real Estate Investment on Economic Growth exceeds that of Economic Growth on Real Estate Investment. Money supply in the market playsa more important role to the real estate investment increase.
\end{abstract}

\section{Introduction}

In recent years, China's real estate market hasbeen developing very rapidly, the National Bureau of Statistics data shows that China annual real estate investment amounted to 8,601.338billion Yuan in 2013, accounting for $15.12 \%$ gross domestic product (GDP) and $19.70 \%$ fixed asset investment in 2013. With the expansion, real estate investment has become an important factor in economic growth and fluctuations, and the problems which resulted from the part prosperous of real estate investment are becoming serious day by day. Liming Hong (2014) [1] pointed out that the Real Estates Investment(REI) is not only an important factor in the impact of short-term fluctuations in the economy, meanwhile, underlying huge risk may lead to the decending economy in the long run.

Although the relationship between REI and Economic Growth has long been paid much attention to by researchers, there are many differences in different conclusions. Some adopted Econometric approach to analyze the relationship between REI and Economic Growth. Jean Gauger(2003)[2] researched in the relationship between REI and macro economy using Error Correction Model (ECM), considering financial regulation,currency,interest and Yield. They found that when the financial regulation was loose, ERI could promote the GDP growth. Timothy O. Bisping and Hilde Patron(2008)[3] studied the impact of residential and non-residential investment on American economic growth using Generalized Impulse Response approach, results showed that residential investment made a greater difference. Jie Zhang, Jianhua Wang and Aiyong Zhu(2012)[5] used the panel data of 30 provinces in China over the period from 1999 q1 to 2007 q4 to implement a preliminary empirical test on the relationship between REI and GDP growthbased on panel Granger approach, and they found that real estate investment could not exert a significant effect on GDP growth when per capita GDP was lower than \$1,000. Yu Ren and Yufei Yuan(2014)[6] established a dynamic stochastic partial equilibrium model for explaining residential investment dynamics in the United States, in this model, when interest rates were exogenously fixed, residence investment resulted in economic growth.

Some others used input-output method to analyze the relationship, Yong Li(2013)[7] studied the driving effect of REI on national economy by calculating the direct consumption coefficient and complete consumption coefficient of China real estate industry in 2010. Chu Meng(2013)[8] analyzed the panel data of 28 provinces in China from 2001 to 2008 using input-output model, and 
they found REI led to economic growth through relevant industries,and current influence coefficient of REI on national economic growth was 0.30. ZhaoHui Wei(2013)[9] calculated the contribution of real estate industry on Sichuan economic growth from the angle of national account, taking multiplier effect into account, and the average contribution of Sichuan real estate industry was $12.8 \%$, leading to GDP growth by $1.9 \%$, which was lower than common expectation.

In this paper,an empirical study will be carried out on the relationship between Real Estate Investment and Economic Growth, combining econometrics and input-output method. At first,a preliminary analysis on the status of REI, economic growth and fixed investment will be made, which is based on input-output method and National economic accounting theory.

\section{Real Estate Investment Status}

The scale of REI has been expanding since 2000, and the share of REI in GDP is on rise year by year, which means REI has become a dominating force in stimulating domestic demand.Figure 1 shows that REI in 2000 was 498.405 billion Yuan, and increased to 8601.338 billion Yuan in 2013.the share of REI in GDP rised from 5.02\% in 2000 to $15.12 \%$ in 2013.The proportions of Real estate in fixed assets remained around $17 \%$.

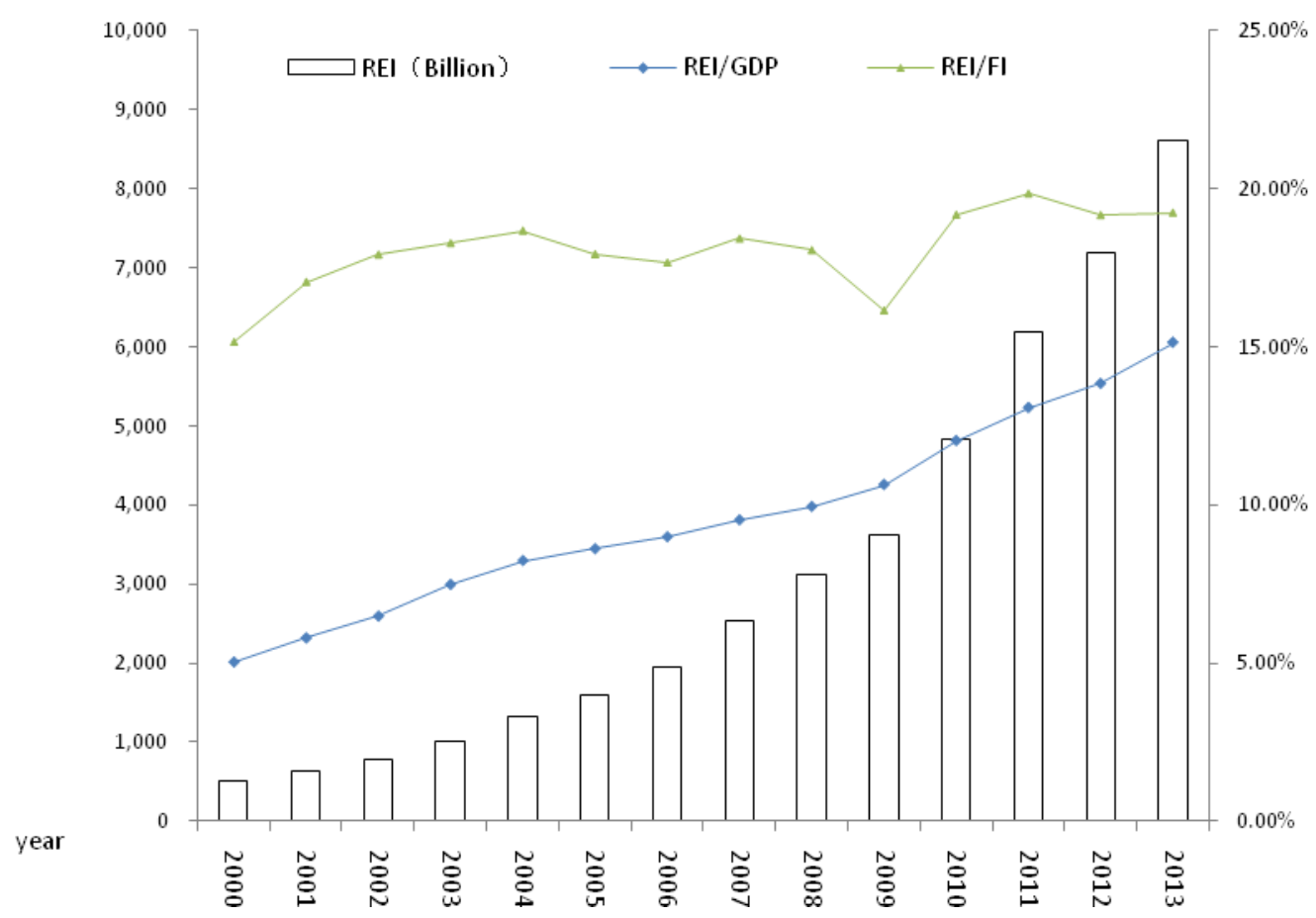

Source: national bureau of statistics

Figure 1 National Real Estate Investment Trends and proportion

\section{Calculation of real estate investment's positive effect on economic growth}

In this paper,three indicators, including REI's dependency on GDP growth, REI's contribution to economic growth, percentage of GDP growth that REI enhances [10], are used to calculate REI'spositive effect on economic growth, based on national accounting theory.

As is shown in fig.2, real estate investment's dependency is Between 0.05 to 0.15, and keep increasing steadily. In 2013, real estate investment dependency reached the peak, which is 0.1512.The growth speed of REI is faster than that of GDP. 


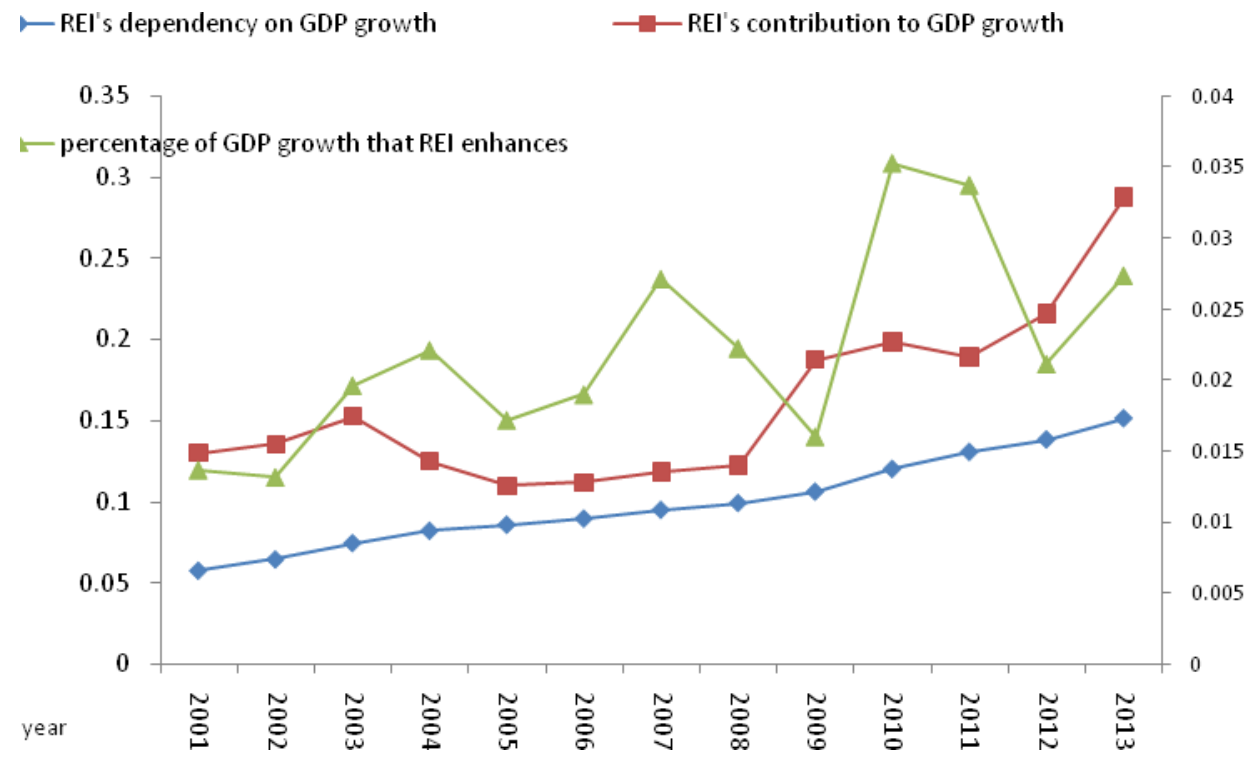

Source: National Bureau of Statistics

Figure 2 trends related economic indicators

REI's contribution to GDP growth has been fluctuating during recent years. Because of the finance crisis in 2008, the Chinese government invested much to fixed asset, including real estate industry. So REI's contribution to GDP growth increased repaidly after 2009.

The percentage of GDP growth that REI enhances is small, which is between 1.3\%-3.5\%. But the gap between the peak and valley is big. It reached a peak of $3.5 \%$ in 2010. Analysis shows that REI growth accords with economic development. The linear correlation coefficient of the the two variables is 0.9806 , revealing strong interdependent relationship.

\section{Analysis of real estate investment growth and economic growth}

The growth level of China's real estate investment is almost the same asfixed investment growth level and economic growth level, which are allperiodic. From 1996 to 1999, the financial crisisattacked Asia. As a result, China's GDP growth fell, the corresponding real estate investment decreases $1.2 \%$ and fixed investment growth slow down.

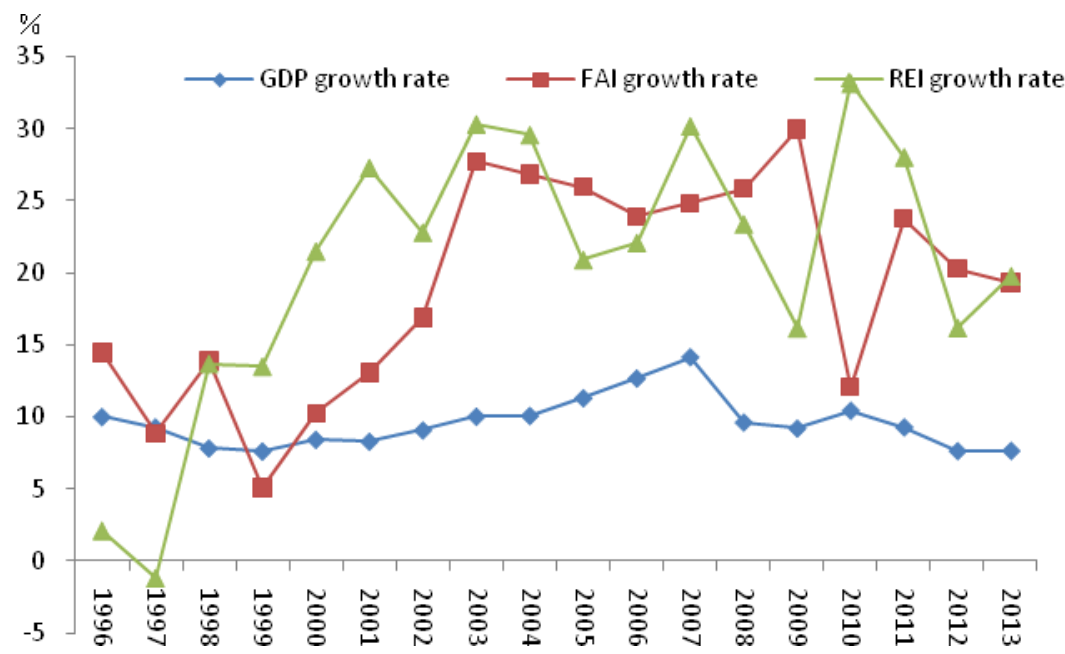

Source: National Bureau of Statistics

Figure 3 GDP,FAI,REI growth rate during 1996 to 2013 
After 1999, the macroeconomic situation changed and the governmentintroduced a series of fiscal policies and monetary policy to promote economic growth. Real estate investment was started with a new wave of expansion, so did investment in fixed assets. Real estate investment increased $30.33 \%$ in 2003.

Figure 3 illustrates that China's real estate investment tended to rise with fluctuations and monetary policy guidancemakes a remarkableeffect on real estate investment. Real estate investment has a positive correlation with investment in fixed assets as well as the macroeconomic level. But the growth rate of real estate development investment is significantly higher than GDP growth rate. The former is almost twice of the latter, which indicates that there is an overinvestment tendency in real estate industry.

\section{Conclusion}

In the long run, China's real estate industry comes with the reforms of housing system and land use system. It is gradually established and developed under the influence ofgradualness of all kinds of economic policies in a variety of economic situation.

After 2003, due to the overheated investment, the state adopted a new round of macro-control such as moderately controlling the scale of investment and adjusting the investment structure. Asa result, real estate investment began to decline.

Real estate investment increased $30.2 \%$ in 2007. Sustained and rapid economic growth played an important role in keeping real estate development and investment increasing.

From 2008 to 2009, due to the US subprime crisis, the external demand played a less important role on the investment growth. The domestic monetary policy became to tighten, the land environment regulationkeptbeing strengthened and the growth of GDP slow down, therefore, real estate investment growth fell back.

Since 2010, the world economic recovery has beenlacking power and monetary policyhas turned steady, which contributed to restrain China's GDP growth. As affordable housing construction proceeded all around, fixed asset investment of the whole society increasesto a higher level.

This paper executes a research on the relation between REI and economic growth. Following are the conclusions:

1) The relation between REI and economic growth is not symmetrical. Economic has a great effect on REI while REI has less impact on economic growth. So when economic change happens, REI will fluctuate wildly.

2) REI crow out other investments in FI. When real estate industry makes more money, large amount of money will flow into this industry.

3) M1 growth accelerates REI growth, also, it accounts for overheated REI growth.

\section{Acknowledgement}

This paper belongs to Research on Districts Resource and Environment Carrying Capacity (Project Number: 1212011088020), which was financially supported by China Geological Survey.

\section{References}

[1] Liming Hong.The Dynamic Relationship between Real Estate Investment and Economic Growth: Evidence from Prefecture City Panel Data in China:Original Research Article[J].IERI Procedia. 2014(7): 2-7.

[2] Jean Gauger.Residential Fixed Investment and the Macroeconomy: Has Deregulation Altered Key Relationships? [J].Journal of Real Estate Finance and Economics,2003, 27(3):335-354.

[3] Timothy O.Bisping,Hilde Patron.Residential Investment and Business Cycles in an Open Economy: A Generalized Impulse Response Approach[J].Real Estate Finan Econ,2008(37):33-49. 
[4] Pesaran MH\& ShinY. Generalized impulse response analysis in linear multivariate models[J]. Economics Letters.1998(58):17-29.

[5] Jie Zhang,Jianhua Wang,Aiyong Zhu.The relationship between real estate investment and economic growth in China: a threshold effect[J]. Ann Reg Sci,2012(48):123-134.

[6] Yu Ren, Yufei Yuan. Why the Housing Sector Leads the Whole Economy: The Importance of Collateral Constraints and News Shocks[J].Real Estate Finan Econ,2014(48):323-341.

[7] Meng chu.Real estate investment's effect on economic growth:based on province data in China[D].Zhejiang:Zhengjiang University,2013.

[8] Li Yong. The analysis about the relationship of real estate investment and growth of national ec onomy[D]. Harbin :Harbin University of Commerce,2013.

[9] Wei Caohui. The research of the real estate industry effect on economic growth-based on Sichuan province data $[\mathrm{J}]$. Southwest Finance, 2013 (9):38-40.

[10] Wang wangping,Xie yanzhao,Zhang zhou.Research on relation between real estate investment and economic growth[J].China Real Estate:Professinoal,2012(10):19-24. 